\title{
Some Properties of a Thermolabile Antigen of Erysipelothrix rhusiopathiae
}

\author{
By A. W. GLEDHILL \\ Institute of Animal Pathology, Cambridge
}

\begin{abstract}
SUMMARY: The production of a thermolabile, somatic antigenic modification by growth of Erysipelothrix in media containing serum has been demonstrated in vitro by agglutinin-absorption methods and by passive protection of mice against infection. Suspensions produced by growth in serum media have been termed OL-suspensions, to signify their possessing both the thermostable $\mathrm{O}$-antigen, and a labile L-antigen.

OL-suspension stimulated the production of immune sera in rabbits which protected mice fully against infection with the homologous strain and partly against infection with the other strains tested. Such sera contained agglutinins against the thermostable $\mathrm{O}$-antigens, agglutinins against the thermo-labile $\mathrm{L}$-antigen and protective antibodies. The three types of antibodies apparently exist both as separate molecules and united in the same molecule, suggesting that the antigenic groups stimulating them exist united in the same antigenic molecules in the organism. The bearing of this suggested polyspecificity of the antigenic substance of Erysipelothrix upon previous work is discussed.
\end{abstract}

In a previous publication (Gledhill, $1945 a$ ) it was shown that most strains of Erysipelothrix may be assigned by agglutinin-absorption methods to one or another of three groups; the remainder, for convenience, to a fourth group. No thermolabile antigens were found and no qualitative differences between the groups were demonstrated, every strain tested being capable of absorbing the agglutinins from sera prepared against other strains. It was shown subsequently (Gledhill, 1945b) that bacterial suspensions, prepared by killing centrifuged cultures grown in glucose broth by heat or merthiolate, induced sera in rabbits which did not protect mice against lethal infection with Erysipelothrix, although they gave partial protection, as judged by increased time of survival of the infected mice. On the other hand, living bacteria produced sera that protected mice against lethal infection with the strains used for immunization. It was not easy to absorb the protective antibody from such sera with bacterial suspensions, which suggested that the protective antibody was an antitoxin. This explanation is not, however, consistent with the fact that bacterial suspensions will readily absorb the protective antibody from protective horse sera prepared in a similar way. Moreover, there is no direct evidence that strains of Erysipelothrix produce an exotoxin.

The immunizing suspensions were prepared by growing cultures in glucose broth. This paper reports the effect of growth in serum broth, which results in the production of bacteria with thermolabile antigens. Furthermore, these bacteria killed with merthiolate produce in rabbits protective sera for mice, comparable in potency with the sera produced by immunization with living cultures. The results suggest that the antigenic properties of Erysipelothrix are 
better explained by the hypothesis that its antigenic groups are present in single antigen molecules, rather than by the hypothesis that each reactive group represents a separate antigen molecule.

\section{Methods}

The strains of E. rhusiopathiae employed were of high virulence for mice. Suspensions from these strains prepared by centrifuging glucose broth cultures and resuspending the deposit in normal saline containing $1: 2000$ merthiolate, as previously described, are referred to as $\mathrm{O}$-suspensions. Suspensions prepared by the same technique from cultures in $1 \%(\mathrm{v} / \mathrm{v})$ horse serum broth, are called OL-suspensions, and usually consisted of a strain that had been subcultured daily in serum broth for about ten days.

Preparation of antisera. To economize antigen, the immunizing dose previously used in rabbits was reduced to approximately a quarter.

As will become evident later, it was important to know that the bacteria were in fact all killed by the merthiolate. This was tested by direct plating, discovered by trial to be in vitro the most sensitive method, and by mouse inoculation. In the experiments described below all antigens are merthiolatekilled unless otherwise stated.

Test of antisera. Antisera were tested both for agglutinins and their power to protect mice against infection with a dose of virulent organisms having an opacity equal to that of 100,000 Bact. coli per ml., which represents about 2000 minimal lethal doses (M.L.D.). Absorptions were carried out for three days at room temperature. The technique of these tests was described by Gledhill $(1945 a, b)$.

\section{EXPERIMENTAL}

The induction of an antigenic modification by growth in serum broth

The antigenic modification induced by growth in serum broth is demonstrable by agglutinin-absorption and by mouse protection tests.

(a) Demonstration of antigenic modification by absorption of agglutinin. A protective antiserum (A 73) prepared against viable group I strain 1224 was absorbed with the homologous $\mathrm{O}$-suspension. The resulting absorbed serum was free from O-agglutinins, but agglutinated OL-suspensions. An antiserum (984) was prepared against the merthiolate-killed OL-suspension of the group II strain EW 2 and absorbed with the homologous $\mathrm{O}$-suspension. This absorbed serum, free from O-agglutinins, also contained L-agglutinins (Table $\mathbf{1}$ ). It is to be noted that the OL-suspension of strain 1224 was not agglutinated by the absorbed serum 984. However, another serum (987), prepared in a different rabbit against the OL-suspension of the same strain EW 2 and absorbed with the homologous $\mathrm{O}$-suspension as in the case of serum 984, was found to agglutinate the OL-suspension of 1224, the titres of this absorbed serum against the OL-suspensions of EW 2 and 1224 being 1:640 and 1:160 respectively. The inability of absorbed serum 984 to agglutinate OL-suspension of strain 
1224 suggests that the modification induced by growth in serum media may be complex (see below).

(b) Demonstration of antigenic modification by mouse protection experiments. The above observations suggested that sera prepared against merthiolatekilled OL-suspensions might be protective for mice in the way that sera against viable cultures are protective. A serum (904) prepared against an OL-suspension of strain EW 2 was titrated in mice infected $24 \mathrm{hr}$. later with the usual dose of the virulent homologous strain. A dose of $0.1 \mathrm{ml}$. of serum protected all of

Table 1. Titres with OL-suspensions of antiserum prepared (a) against living 1224 and $(b)$ against killed OL-suspensions of EW2, each absorbed with its homologous $\mathrm{O}$-antigen

$\begin{array}{lccc}\text { Antigen } & \text { Group } & (a) \text { Serum A73 } & (b) \text { Serum 984 } \\ \text { EW6 } & \text { I } & 1: 80 & 1: 160 \\ \text { 1224 } & \text { I } & 1: 160 & - \\ \text { Ru } & \text { I } & 1: 160 & 1: 160 \\ \text { AE5 } & \text { I? } & 1: 40 & 1: 160 \\ \text { EW2 } & \text { II } & 1: 80 & 1: 160 \\ \text { EW 11 } & \text { III } & 1: 80 & 1: 160 \\ \text { V } & \text { III } & 1: 160 & 1: 160 \\ \text { MEW 22 } & \text { IV } & 1: 80 & 1: 160\end{array}$

Neither serum agglutinated the corresponding $\mathrm{O}$-suspensions.

six mice, and a dose of $\mathbf{0 . 0 1} \mathrm{ml}$. only two out of six mice. Four control mice died in an average time of $2 \cdot 3$ days and six mice given $0 \cdot 1 \mathrm{ml}$. of a serum prepared against the $\mathrm{O}$-suspension of $\mathbf{E W} 2$ died in an average time of $5 \cdot 3$ days. In further experiments, doses of $0.1 \mathrm{ml}$. of sera 984 and 987 prepared against different batches of EW2 OL-suspension were completely protective. The protective power of these sera were not, therefore, inferior to those described previously prepared against living bacteria. The validity, however, of the conclusion that $\mathrm{OL}$-suspensions stimulate the production of effective immune sera in rabbits rests on the assurance that no viable organisms remained in the suspensions employed. For, if even a few cells remained viable, the efficacy of the resultant immune sera could presumably be attributed to these. The methods of sterility testing were rigorous enough to exclude this possibility. Moreover, $\mathrm{O}$-suspensions killed in the same way have never induced protective antibody in the rabbit (Gledhill, $1945 b$ ).

\section{The lability of the antigenic modification}

(a) Thermolability. It seemed possible that the antigenic modification might be thermolabile, in view of the well-known difficulty of immunizing pigs with heat-killed vaccines prepared in various ways. The thermolability of the new antigen was determined by following the consequences of heat treatment upon its agglutinability by $\mathbf{L}$-antisera and upon its power to induce mouse-protective antibodies in the rabbit.

The agglutinating titre of serum A73, prepared against viable group I strain 1224 and absorbed with homologous $\mathrm{O}$-suspension, was determined for 
five portions of a single merthiolate-killed OL-suspension of EW 2 maintained for $\frac{1}{2} \mathrm{hr}$. at $55^{\circ}, 65^{\circ}, 75^{\circ}, 90^{\circ}$ and $100^{\circ}$ respectively. None of the heated suspensions was agglutinated at the lowest dilution tested $(1: 20)$, whereas the titre with unheated suspension was $1: 8,0$.

Similarly treated portions of EW 2 OL-suspension were used to immunize rabbits. The protective effect of the resulting sera in mice shows that the new antigen is completely destroyed in $\frac{1}{2} \mathrm{hr}$. at $75^{\circ}$ and largely destroyed at $55^{\circ}$ (Table 2).

Table 2. The protective power of antisera prepared against merthiolate-killed OL-suspensions of EW 2 heated to various temperatures

$\begin{array}{clccc}\begin{array}{c}\text { Rabbit } \\ \text { no. }\end{array} & \begin{array}{c}\text { Treatment of immunizing } \\ \text { suspension }\end{array} & \begin{array}{c}\text { Dose of } \\ \text { antiserum } \\ \text { (ml.) }\end{array} & \begin{array}{c}\text { Death-rate } \\ (6 \text { mice) }\end{array} & \begin{array}{c}\text { Average } \\ \text { time to } \\ \text { death } \\ \text { (days) }\end{array} \\ 984 & \text { Unheated } & 0 \cdot 1 & 0 / 6 & - \\ 984 & \text { Unheated } & 0 \cdot 05 & 2 / 6 & 14 \cdot 0 \\ 980 & \text { Heated to } 55^{\circ} \text { for } 30 \text { min. } & 0 \cdot 1 & 3 / 6 & 5 \cdot 0 \\ 980 & \text { Heated to } 55^{\circ} \text { for } 30 \text { min. } & 0 \cdot 05 & 6 / 6 & 6 \cdot 0 \\ 906 & \text { Heated to } 65^{\circ} \text { for } 30 \text { min. } & 0 \cdot 1 & 3 / 6 & 6 \cdot 7 \\ 862 & \text { Heated to } 75^{\circ} \text { for } 30 \text { min. } & 0 \cdot 1 & 6 / 6 & 6 \cdot 2\end{array}$

(b) Ethanol resistance. A batch of growth was treated for $48 \mathrm{hr}$. at room temperature with ethanol by the method of Henderson (1937). The ethanol was removed by centrifugation and the suspension, after washing three times in saline, was used to immunize a rabbit. The serum in a dose of $0.3 \mathrm{ml}$. completely protected six mice against the usual infecting dose of organisms. With a dose of $0.1 \mathrm{ml}$. two out of six mice survived, the four dying in an average time of $7 \cdot 0$ days as compared with $3 \cdot 3$ days for the controls. On the other hand, $0.1 \mathrm{ml}$. of serum prepared by immunizing another rabbit with merthiolate-killed antigen obtained from the same batch of growth failed to protect two out of six mice. It appears that the antigen stimulating the production of protective antibodies in rabbits was not destroyed by the ethanol treatment.

It may be concluded from these experiments that the growth of Erysipelothrix in the presence of horse serum induces a somatic, thermolabile, antigenic modification, resistant to ethanol. The somatic Vi-antigen, described by Felix \& Pitt (1934) in virulent strains of the typhoid group of bacteria, is thermolabile and ethanol resistant. Whether the antigenic modification of Erysipelothrix by growth in serum resembles the Vi-antigen depends on the definition of Vi-antigens. The antigenic modification, as somatic and thermolabile, accords with the classical notion of Vi-antigen. On the other hand, the antigenic modification of Erysipelothrix is not strictly associated with virulence since a number of strains of low virulence-for instance 1224 and EW 11 of Table 1-produce it, although several rapid transfers in serum media may be necessary before its presence can be demonstrated. Strains in the partially rough phase do not appear to produce it. There is, however, no doubt that a smooth strain devoid of L-antigen as a result of growth in broth without 
serum, may be induced to produce it by growth in the presence of serum. Hence, the presence of serum does not serve merely to hinder or prevent an irreversible antigenic degradation consequent upon maintaining cultures in vitro. In fact, the antigenic modification is induced by the medium selected for growth. Whether the loss of the capacity to produce the antigenic modification is reversible is, however, a different question.

\section{The specificity of the antigenic modification}

In the experiments so far described, only sera against OL-suspensions of the group II strain EW2 were used. The agglutination tests with absorbed sera shown in Table 1 suggest that the antigenic modification is not strain specific.

Table 3. The cross-protection afforded by antisera prepared against $O L$-suspensions

The dose of serum was $0 \cdot 1 \mathrm{ml}$. per mouse.

All 15 controls died in average times of $3 \cdot 2$ days for $\mathrm{EW} 2$ and $3 \cdot 0$ days for each of $\mathrm{Ru}$ and $\mathrm{V}$.

\begin{tabular}{|c|c|c|c|c|}
\hline \multicolumn{2}{|c|}{ Protective serum } & \multirow[b]{2}{*}{$\begin{array}{l}\text { Infecting } \\
\text { strain }\end{array}$} & \multirow[b]{2}{*}{$\begin{array}{c}\text { Death-rate } \\
\text { (5 mice) }\end{array}$} & \multirow{2}{*}{$\begin{array}{c}\text { Average } \\
\text { time to } \\
\text { death } \\
\text { (days) }\end{array}$} \\
\hline $\begin{array}{c}\text { Rabbit } \\
\text { no. }\end{array}$ & $\begin{array}{c}\text { Prepared } \\
\text { against }\end{array}$ & & & \\
\hline 984 & EW2 (II) & $\begin{array}{l}\text { Ru (I) } \\
\text { EW2 (II) } \\
\text { V (III) }\end{array}$ & $\begin{array}{l}1 / 5 \\
0 / 5 \\
2 / 5\end{array}$ & $\frac{5 \cdot 0}{6 \cdot 5}$ \\
\hline A26 & $\mathrm{Ru}(\mathrm{I})$ & $\begin{array}{l}\text { Ru (I) } \\
\text { EW2 (II) } \\
\text { V (III) }\end{array}$ & $\begin{array}{l}0 / 5 \\
3 / 5 \\
1 / 5\end{array}$ & $\begin{array}{l}\overline{7 \cdot 3} \\
10 \cdot 0\end{array}$ \\
\hline A5 & V (III) & $\begin{array}{l}\text { Ru (I) } \\
\text { EW2 (II) } \\
\text { V (III) }\end{array}$ & $\begin{array}{l}1 / 5 \\
2 / 5 \\
0 / 5\end{array}$ & $\begin{array}{c}10 \cdot 0 \\
10 \cdot 5 \\
-\end{array}$ \\
\hline
\end{tabular}

It is to be expected that the protective power of such sera would likewise be species specific, especially since sera against viable cultures are not strain specific. To test this point sera were made against the OL-suspensions of the group I strain $\mathrm{Ru}$ and the group III strain $\mathrm{V}$, in addition to serum 984 against the group II strain EW 2. Strains Ru and V were chosen because they were highly virulent for mice and therefore suitable for infecting the test mice and, with EW 2, represented the heat-stable antigens of all three groups. The protective power of the sera is shown in Table 3. It is clear that the crossprotection by these sera is inferior to the protection by sera against the homologous strain and especially so in the case of the serum prepared against strain $\mathrm{Ru}$. Nevertheless, that there is some degree of cross-protection is evident when it is recalled that the infecting dose was about 2000 M.L.D. and that mice receiving anti-O sera do not survive infection with such a dose of virulent organisms. For example, of forty-five mice injected with sera of this kind, forty-three died in an average time of 4.7 days, the two survivors being from an experiment in which the virulence of the infecting organisms was somewhat reduced, judged by the time of survival of the controls. This imperfection of the strain specificity of the antigenic modification again suggests that it may be complex. 


\section{The complexity of the antigenic modification}

The following experiments suggest that the antigen is dual in that it stimulates in rabbits agglutinins and protective antibodies, which can occur in antisera as separate particles.

Serum 984, prepared against the OL-suspension of strain EW2 (II) and absorbed with the homologous $\mathrm{O}$-suspension, agglutinates OL-suspensions but not $\mathrm{O}$-suspensions of other strains (Table 1), but was unable to protect mice against the usual dose of homologous infecting organisms. On the other hand, absorbed serum 987 , prepared in the same way as 984 , against the same strain EW 2, not only agglutinated OL-suspensions but gave a significant measure of

Table 4. Agglutinin content and protective power of antisera absorbed with O-suspensions

The dose of serum was $0.1 \mathrm{ml}$. per mouse.

All the 16 controls died in an average time of $3 \cdot 4$ days.

\begin{tabular}{|c|c|c|c|c|c|}
\hline \multirow{2}{*}{$\begin{array}{c}\text { Rabbit } \\
\text { no. }\end{array}$} & \multicolumn{2}{|c|}{ Serum } & \multirow{2}{*}{$\begin{array}{c}\text { Aggluti- } \\
\text { nating titre } \\
\text { of absorbed } \\
\text { serum } \\
\text { against } \\
\text { EW2 OL- } \\
\text { suspension }\end{array}$} & \multirow{2}{*}{$\begin{array}{l}\text { Death- } \\
\text { rate } \\
\text { (5 mice) }\end{array}$} & \multirow{2}{*}{$\begin{array}{c}\text { Average } \\
\text { time to } \\
\text { death } \\
\text { (days) }\end{array}$} \\
\hline & Prepared against & Absorbed with & & & \\
\hline 984 & EW 2 OL-antigen & EW 2 O-antigen & $1: 160$ & $5 / 5$ & $3 \cdot 6$ \\
\hline 987 & EW 2 OL-antigen & EW2 O-antigen & $1: 640$ & $2 / 5$ & $10 \cdot 5$ \\
\hline 863 & EW 2 viable & EW2 O-antigen & $>1: 10$ & $0 / 6$ & - \\
\hline A73 & 1224 viable & 1224 $\mathrm{O}$-antigen & $1: 160$ & $4 / 4$ & $8 \cdot 0$ \\
\hline
\end{tabular}

protection to mice. Serum 863, prepared against viable EW2 and absorbed with the homologous $\mathrm{O}$-suspension, failed to agglutinate $\mathrm{OL}$-suspensions, yet gave good protection to mice, and serum A273 against viable 1224 did not protect mice after absorption with the homologous $O$ strain, although it remained capable of agglutinating OL-suspensions (Table 1). The details of these experiments are shown in Table 4. Moreover, when the strain EW2 is grown in rabbit or pig serum broth, the growth, like that in horse serum broth, is agglutinated by absorbed OL-antisera. Yet it did not induce protective antibodies for mice on injection in the rabbit (Table 5). This result also suggests that the modification induced by growth in serum media is complex. It is of interest that the Vi-antigen of Salm. typhi appears to be similarly complex in that antisera to formolized broth cultures of Vi typhoid bacilli agglútinate virulent typhoid bacilli although conferring very feeble protective powers upon mice (Felix \& Bhatnagar, 1935). Nevertheless, antisera to living virulent typhoid bacilli contain both agglutinating and protective antibodies.

Since protective antibodies appear to be distinct from specific agglutinins for OL-suspensions, the fact that the agglutinogen is attached to the organisms does not entail that the antigen inducing the protective antibody is so attached, it might exist in solution in the suspending fluid. However, the bulk of the antigen appears to be attached to the bacterial bodies, for ethanol-treated, washed bacteria will induce protective antibodies in a rabbit. This hypothesis 
has been confirmed in a number of experiments in which the bacteria were treated chemically with a view to liberating the antigen; the bulk of the antigen remained attached to the killed organisms, as shown by the superior antigenicity of the treated organisms as compared with the supernatant fluid from the treated suspension.

Table 5. Protective power of antisera prepared against suspensions grown in media containing horse, rabbit and pig serum

The dose of serum was $0 \cdot 1 \mathrm{ml}$. per mouse.

All 15 controls died in an average time of $3 \cdot 3$ days.

The suspensions used for preparing the three sera were all agglutinated to the same titre $(1: 160)$ by serum 984 absorbed with the homologous $\mathrm{O}$-antigen.

$\begin{array}{cccc}\text { Rabitt } & \begin{array}{c}\text { Protective serum } \\ \text { against antigen pre- } \\ \text { pared by growth in }\end{array} & \begin{array}{c}\text { Death-rate } \\ (5 \text { mice })\end{array} & \begin{array}{c}\text { Average time } \\ \text { to death } \\ \text { (days) }\end{array} \\ 984 & \text { 1\% horse serum } & 0 / 5 & - \\ \text { A6 } & 1 \% \text { rabbit serum } & 5 / 5 & 5 \cdot 6 \\ \text { A16 } & \text { 1\% pig serum } & 5 / 5 & 10 \cdot 6\end{array}$

\section{DISCUSSION}

Reasons have been advanced for assuming the complexity of the thermolabile somatic antigenic modification of Erysipelothrix rhusiopathiae induced by growth in serum media. The immunological data upon which this assumption is based are summarized in Table 6. From the absorption experiments it

Table 6. Summary of the results of the immunological tests

\begin{tabular}{|c|c|c|c|c|c|}
\hline \multirow[b]{3}{*}{ Serum } & \multirow{3}{*}{$\begin{array}{l}\text { Nature of } \\
\text { immunizing } \\
\text { suspension }\end{array}$} & \multirow[b]{3}{*}{$\begin{array}{l}\text { Absorbing } \\
\text { suspension }\end{array}$} & \multicolumn{3}{|c|}{ Residual antibody effect } \\
\hline & & & \multirow[b]{2}{*}{ Protective } & \multicolumn{2}{|c|}{ Agglutinin } \\
\hline & & & & $\mathbf{L}$ & $\mathbf{O}$ \\
\hline Previous paper & Living cells & $\begin{array}{l}\text { Nil } \\
\text { O }\end{array}$ & $\begin{array}{l}+ \\
+\end{array}$ & $\begin{array}{l}\text { nt } \\
\text { nt }\end{array}$ & + \\
\hline Previous paper & $\mathbf{O}$ & Nil & - or \pm & nt & + \\
\hline A73 & Living cells & $\begin{array}{l}\text { Nil } \\
\text { O }\end{array}$ & + & $\begin{array}{l}+ \\
+\end{array}$ & $\begin{array}{l}+ \\
-\end{array}$ \\
\hline 984 & OL & $\begin{array}{l}\text { Nil } \\
\mathrm{O}\end{array}$ & $\begin{array}{l}+ \\
-\end{array}$ & $\begin{array}{l}+ \\
+\end{array}$ & + \\
\hline 987 & OL & $\begin{array}{l}\text { Nil } \\
\mathbf{O}\end{array}$ & $\begin{array}{l}+ \\
+\end{array}$ & $\begin{array}{l}+ \\
+\end{array}$ & $\begin{array}{l}+ \\
-\end{array}$ \\
\hline 863 & Living cells & $\begin{array}{l}\text { Nil } \\
\text { O }\end{array}$ & $\begin{array}{l}+ \\
+\end{array}$ & $\begin{array}{l}+ \\
-\end{array}$ & + \\
\hline
\end{tabular}

would appear that the thermostable $\mathrm{O}$-antigens are sometimes capable of absorbing the majority of the L-agglutinins (serum 863), and are sometimes capable of absorbing the majority of the protective antibodies (sera 984 and A 73). If it is assumed that non-specific absorption did not occur, then sometimes most of the agglutinins for OL-suspensions appear to be associated with 
the $\mathbf{O}$-agglutinins and at others it is protective antibodies that appear to be associated with them. On other occasions neither the agglutinins for OLsuspensions nor the protective antibodies are associated with the $\mathrm{O}$-agglutinins. It is generally believed (see e.g. Dean, Taylor \& Adair, 1935), that the components of a mixture of antigens stimulate antibody production independently of each other. On the other hand, following the work of Heidelberger \& Kendal (1934), it has been suggested that a single antigen molecule, possessing more than one kind of reactive group, can give rise to antibody molecules specific for one group only, for some, or, for all the groups (Marrack, 1938). Generally speaking, antibody molecules of all these kinds would be present, the quantitative distribution of each being subject to wide variation. Certainly prolonged immunization tends to the production of antibodies of less sharp specificity (see Burnet, 1941). It is not clear, however, whether the explanation of this observation is that antibodies with more than one distinct specificity tend to be produced by prolonged immunization or that for other reasons a single specificity tends to be broadened. If the former, the results of the experiments described suggest that the antigenic group stimulating agglutinins against OL-suspension, the antigenic group stimulating protective antibodies and the thermostable antigenic groups are all united in single antigen molecules upon Erysipelothrix organisms. In the light of this hypothesis, the fact that protective antibody is easily absorbed by $\mathrm{O}$-suspensions from horse antisera to viable bacteria and yet not completely absorbable from rabbit antisera to viable bacteria (see Table 5) can be explained as follows. The two sera differ in the concentration of protective antibody molecules as compared with that of dispecific antibody molecules capable of reacting with the thermostable $\mathrm{O}$-antigens and of conferring protection. In horse immune sera, the polyspecific antibodies presumably predominate, monospecific antibodies predominating in rabbit immune sera. The reasons for the difference in concentration of the two kinds of antibody in horse and rabbit antisera are more obscure. Horses are not so easily hyperimmunized against E. rhusiopathiae as rabbits are, and require a more prolonged course of inoculation, with the result that polyspecific antibodies are likely to be produced more abundantly. Alternatively, it might be supposed that growth in serum medium produces a thermolabile antigenic modification without involving the production of any new antigenic groups. Antisera against such a modified antigen would contain some antibodies of sufficiently wide reactivity both to confer protection upon mice and agglutinate $\mathrm{O}$-suspensions; others would confer protection and agglutinate $\mathrm{OL}$-suspensions, not $\mathrm{O}$-suspensions; others, again, would only confer protection. According to this hypothesis, the fact that the protective power of horse immune sera can be absorbed by $\mathrm{O}$-suspensions, whereas that of rabbits cannot, would result if horse immune sera contained a greater proportion of antibodies of wide reactivity than do rabbit sera. No discrimination between these hypotheses is possible other than by determining the differences of chemical structure between purified $\mathrm{O}$ - and $\mathrm{L}$-antigens. In the absence of any real basis for such a discrimination, the former hypothesis is to be preferred in that it justifies the postulation of thermolabile L-antigenic 
groups whereas the latter hypothesis would require that OL-suspensions should differ from $\mathrm{O}$-suspensions in an unknown manner, leading to difficulties in exposition. For example, the notion of bacterial growths in serum media as containing $\mathbf{O}+\mathbf{L}$ antigenic groups would be invalid. Both hypotheses, however, imply that the production in rabbits of all the types of antibodies under discussion is not stimulated by a number of separate antigenic substances in each organism.

In regard to the difficulty previously experienced of completely absorbing with living suspensions the antibodies in rabbit sera prepared against such suspensions, it is to be noted that the absorbing suspensions were obtained from glucose broth cultures, and would not possess L-antigen. The question whether the thermostable $\mathrm{O}$-antigens investigated previously occur in the organism as separate antigen molecules or whether they are associated with other antigens on the same molecule, does not modify the conclusions previously reached about the relations between the $\mathrm{O}$-antigens of different strains of Erysipelothrix, except perhaps verbally.

The nature and causes of the antigenic modification offers an interesting field for inquiry. Does serum globulin itself, or some other constituent, induce the modification? It is noteworthy that the modifications induced by rabbit and pig sera differ from those induced by horse serum in their apparent inability to produce protective antibodies. The difference resembles the differences of virulence of organisms induced by passage in different species of animals. Hence, a knowledge of the nature of the serum-induced modification might have some bearing upon the wider question of the variations in virulence of strains of E. rhusiopathiae. The observation that viable organisms, grown in glucose broth, centrifuged and suspended in serum do not acquire the $\mathrm{L}$-antigenic modification, and the fact that the antigenic modification is best produced by several rapid subcultures in serum media, suggest that active multiplication is necessary for the production of the L-antigen. Finally, there is the question as to whether the loss of the capacity to modify when grown in serum can be correlated with the $\mathbf{S} \rightarrow \mathbf{R}$ change and whether such loss is reversible. The possible bearing of the answers to these questions upon the epidemiology of the disease in pigs and other animals is obvious.

From the more immediate practical standpoint, the possibility that killed OL-suspensions might prove successful in the active immunization of pigs against swine erysipelas is of some importance, since such vaccines would be safer and more economical than the simultaneous administration of living bacilli and immune serum used at present.

\section{REFERENCES}

Burnet, F. M. (1941). The Production of Antibodies, p. 28. Melbourne: Macmillan and Co. Ltd.

Dean, H. R., TAYlor, G. L. \& AdaIr, M. E. (1935). The precipitin reaction. Experiments with an antiserum containing two antibodies. J. Hyg., Camb., 35, 69.

Felix, A. \& Bhatnagar, S. S. (1935). Further observations on the properties of the Vi-antigen of B. typhosus and its corresponding antibody. Brit. J. exp. Path. 16, 422 . 
Felix, A. \& Pitt, R. M. (1934). Virulence of B. typhosus and resistance to $O$ antibody. J. Path. Bact. 38, 409.

Gledhild, A. W. (1945a). The antigenic structure of Erysipelothrix. J. Path. Bact. $57,179$.

Gledhill, A. W. $(\mathbf{1 9 4 5} b)$. The passive protection of mice against infection with E. rhusiopathiae. J. comp. Path. 55, 93.

Heidelberger, M. \& Kendald, F. E. (1934). Quantitative studies on the precipitin reaction. The role of multiple reactive groups in antigen-antibody union as illustrated by an instance of cross-precipitation. J. exp. Med. 59, 519.

Henderson, D. W. (1937). A serological analysis of the protective substances in specific antibacterial sera which control experimental infection with $\mathrm{Cl}$. oedematis maligni (Vibrion Septique). Brit. J. exp. Path. 18, 224.

Marrack, J. R. (1938). 'The chemistry of antigens and antibodies. Spec. Rep. Ser. med. res. Coun., Lond., no. 230. 